\title{
Sınır Ötesi Tarım Yatırımlarının Geleceği ve Ülkelerin Sınır Ötesi Tarım Yatırımı İhtiyacının Tespiti İçin Bir Yaklaşım ${ }^{1}$
}

Adem GÜLGÖNÜL ${ }^{2}$ Elife AKİ̧̧ ${ }^{3}$

\begin{tabular}{lcc}
\hline \multicolumn{1}{c}{ Geliş Tarihi/ Received } & Kabul Tarihi/ Accepted & Yayın Tarihi/ Published \\
18/12/2019 & $02 / 04 / 2020$ & $15 / 04 / 2020$ \\
\hline Citation/Atıf: Gülgönül, A. ve Akiş, E., (2020), Sinır Ötesi Tarım Yatırımlarının Geleceği ve \\
Ülkelerin Sinır Ötesi Tarım Yatırımı İhtiyacının Tespiti İçin Bir Yaklaşım, Atatürk Üniversitesi \\
İktisadi ve İdari Bilimler Dergisi, 34(2): 531-553, DOI: 10.16951/atauniiibd.661243 \\
\hline
\end{tabular}

Öz: Bu çalışmada, dünya nüfusunun gıda talebinin uzun vadede karşılanarak gıda krizlerinin önlenebilmesinde sınır ötesi tarım yatırımlarının etkisine odaklanılmışıtır. İklim değişikliğinin olumsuz etkileri, ülkelerin gelişmişlik düzeylerine paralel olarak tüketim kalıplarının değişmesi, nüfusun artması, ekilebilir tarım alanlarının azalması, tarım arazilerinin biyoyakıt ve madencilik gibi tarım dışı amaçlarla kullanılmaya başlanması nedeniyle ülkelerin büyük çoğunluğunun sınır ötesi tarım yatırımı yapması gerektiği bulgusuna ulaşılmıştır. Bu bulgunun desteklenmesi için, ülkelerin ekilebilir tarım arazileri ile nüfusları arasında bir ilişki kurularak bir ülkenin tarım arazisi ihtiyacı/fazlası belirlenmeye çalışılmıştır. Dünya Bankası tarafından yayınlanan 2016 yılı verilerine göre; ekilebilir tarım arazilerinin toplamı dünya nüfusuna bölündüğünde kişi başına düşen ortalama ekilebilir arazi miktarı 0,19 hektar büyüklügüne denk gelmektedir. Bu rakamın ideal büyüklük olduğu varsayımıyla; dünyadaki ekonomik büyüklük açısından en büyük 20 ülkenin ekilebilir arazi miktarları ve nüfusları dikkate alınarak sınır ötesi tarım yatırımı ihtiyacı için bir çalışma yapılmıştır.

Anahtar Kelimeler: Sınır ötesi tarım yatırımı, tarımın geleceği ve önemi, iktisadi büyüme ve kalkınma

The Future of Foreign Agricultural Investments and an Approach for Determining Countries' Need for Foreign Agricultural Investment

Abstract: This study focuses on the impact of foreign agriculture investments in preventing food crises by satisfying the long-term food demand of the world population. The negative effects of climate change, changes in consumption patterns in parallel with the development levels of the countries, growth in the population, the decrease in arable agricultural areas, the use of agricultural land for non-agricultural purposes such as biofuels and mining have led to the conclusion that the majority of countries need to invest in foreign agriculture. In order to support this finding, a relationship was established between the arable land and the populations of the

${ }^{1}$ Bu çalışma, Dr. Öğr. Üyesi Elife AKİ̧̧ danışmanlığında İstanbul Üniversitesi Sosyal Bilimler Enstitüsünde yürütülen "Sınır Ötesi Tarım Yatırımları ve Küresel Tarım Yatırımlarının Geleceği”" başlıklı yüksek lisans tezinden türetilmiştir.

${ }^{2}$ Doktora Öğrencisi, İstanbul Üniversitesi, Sosyal Bilimler Enstitüsü, https://orcid.org/0000-00033286-7429

${ }^{3}$ Dr. Öğr. Üyesi İstanbul Üniversitesi, İktisat Fakültesi, İktisat Bölümü, https://orcid.org/0000$\underline{0002-5443-4045}$ 
Sinır Ötesi Tarım Yatırımlarının Geleceği ve Ülkelerin Sinır Ötesi Tarım Yatırımı İhtiyacının Tespiti İçin Bir Yaklaşım

countries to determine the agricultural land need / surplus of a country. According to World Bank data; when the total arable land is divided by the world population, the average arable land per capita is 0.19 hectares. Assuming this is the ideal size; foreign agriculture investment need modeling has been made by taking into account the arable land size and population of the top 20 countries in terms of economic size in the world.

Keywords: Foreign agriculture investment, future and importance of agriculture, economic growth and development

\section{EXTENDED SUMMARY}

Research Problem: This study focuses on the impact of foreign agriculture investments in preventing food crises by satisfying the long-term food demand of the world population.

Research Questions: What is the importance of agriculture for countries?

What are the reasons for the increased investments of countries in foreign agriculture investments in recent years?

What is the effect of the policies implemented by the international regulatory agencies while fulfilling the gap that stems from the elimination of farmers and states from the sector, the main actors of the traditional agricultural sector, by the global companies using food as a weapon?

Literature Review: Within the framework of the literature review, databases of institutions such as the World Bank, United Nations, Food and Agriculture Organization of the United Nations, Organization for Economic Cooperation and Development, and European Statistics Office (Eurostat) were used. However, it has been found that there is no global data and up-to-date record system for foreign agriculture investments, and there is no comprehensive, content-rich and up-to-date research or report among the reports published by the international institutions mentioned above. The reports prepared by Land Matrix, GRAIN and the Oxford Poverty Alleviation Committee (OXFAM), which came to the forefront as international non-governmental organizations monitoring and reporting on investments in foreign agricultural lands, were used in this study. Foreign agricultural investments were examined based on the research reports published by these three organizations, and the analyzes were made in the light of the data contained in these reports.

Methodology: In this study, by using the latest data published by the World Bank in 2016, a relationship has been established between the arable land and the population of the countries; and the arable land need / surplus of the countries has been calculated. According to World Bank data, the average amount of arable land per capita in the world is 0,19 hectares. Assuming that 0,19 hectares of arable land per capita is the ideal size; The foreign agricultural investment need / surplus table of these countries has been created by taking into account the arable land size and population of the top 20 countries in terms of their economic size in the world. The population of the countries was multiplied by 0,19 hectares and the required arable land sizes for the country were found. This value is compared with the size of the existing arable land of the countries. 
Results and Conclusions: The negative effects of climate change, changes in consumption patterns in parallel with the development levels of the countries, population growth, the decrease of arable lands, the use of agricultural lands for non-agricultural purposes such as biofuels, mining and tourism have led to the need for a large number of foreign agricultural investments. Decrease in arable land per capita increased the frequency of food crises. Although there is no need for foreign agricultural investment, it is determined that some countries make foreign agricultural investments in order to invest in high-value agricultural products such as coffee, cocoa, sugar, corn and soybeans. Increasing interest of countries and global corporations on agricultural lands at global level causes human rights violations and many environmental problems. It is observed that foreign agricultural investments are focused on countries in sub-Saharan Africa. Foreign agricultural investments have positive and negative consequences both for the investing country and for the invested country. Rather positive results have occurred for the investing countries, while more negative results have occurred in the invested countries.

The most important negative result of foreign agricultural investment trade is the emergence of the land grabbing in the investment countries. Agricultural investments in the form of land grabs lead to displacement of the poor and vulnerable population, increase in poverty and reduced access to food. The land rented or purchased in this way has had more negative impacts on the lives of poor people than on climate change. The agricultural sector, which has been carried out by small enterprises and governments for centuries, has started to be controlled by multinational companies in recent years. The future of the agricultural sector is under the control of a small number of companies that control all processes from seed to pesticide, from marketing to product shipment.

\section{Giriş}

İnsan neslinin devamı için kritik öneme sahip olan çiftçilik, dünyanın en eski mesleklerinden birisidir. Beslenme ihtiyacını gidermek için ilk çağlarda doğada hazır bulduğu gıdalarla hayatını sürdürmeye çalışan insanoğlunun yaşamında tarımın keşfi ile köklü değişiklikler meydana gelmiştir. Yerleşik hayata geçişle birlikte insanların yaşam konforu ve toprağa bağımlılı̆̆

Neolitik dönemden bu yana insanoğlu, doğal ortamın önemli bileşenlerinden biri olan toprağı ve toprak kaynaklarını kendi yararına kullanmaya başlamıştır. Yerleşik yaşama geçişle birlikte tarım ve hayvancılık faaliyetleri hızlanmış, uygun yerlerde köyler ve kentler kurulmaya başlanmıştır (Gülersoy, 2014: 53).

İnsanoğlunun yerleşik hayata geçtikten sonra elde ettiği tarımsal başarılar, insanların hayatını kısa sürede değiştirmiş ve bilinen ilk uygarlıkların temeli verimli topraklarda atılmaya başlamıştır (Gülersoy, 2014: 54-55). 
Sinır Ötesi Tarım Yatırımlarının Geleceği ve Ülkelerin Sinır Ötesi Tarım Yatırımı İhtiyacının Tespiti İçin Bir Yaklaşım

Birincil sektör olması nedeniyle ülkelerin gelişmesi ve kalkınması için bir köprü vazifesi gören tarım sektörü, gelişmişlik düzeyinden bağımsız olarak tüm ülkelerin ekonomik hayatlarında önemli bir yere sahiptir.

Günümüzde gıdanın üretildiği ekolojik alanlar tahrip edilmekte, ekolojik döngü bozulmakta, ekolojik emperyalizm yaşanmaktadır. Gıda konusu bir iktisat veya ziraat mühendisliğinden öte bir siyaset bilimi sorunu olarak karşımıza çıkmaktadır (Reyhan, 2014: 92-93). Gıda güvenliğinin bir mücadele alanı olarak görülmesi gıda krizlerinin yaşanmasını kaçınılmaz hale getirmiştir. Bunun en güncel örneği; 2008 yılında kuraklığın neden olduğu küresel gıda krizi, birçok ülke için ulusal tarım politikalarının yeniden gözden geçirilmesini zorunlu hale getirmiştir. Son 20 yılda sıkça tekrarlanan gıda krizlerinin etkisiyle, tarım politikası ülkeler için milli güvenlik meselesi haline gelmeye başlamıştır.

21. yüzyılın ilk yıllarında yaşanan gida krizlerinin doğal sonucu olarak ülkeler alternatif arayışına girmiştir. Bu çerçevede sınır ötesi tarım yatırımı ticareti gıda talebinin karşılanması noktasında önemli bir alternatif olarak gündeme gelmiştir. Bu yeni ve alternatif tarımsal ticaret modeli, geleneksel olarak tarım sektörünün baş aktörü olan küçük işletmelerin ve devletlerin sektörden tasfiye sürecinin hızlanmasına, gıdayı bir silah gibi kullanan küresel şirketlerin sektördeki egemenliklerinin artmasına neden olmuştur. 2008 yı1ı itibariyle küresel gıda malları ticaretinin \%60'ının çok uluslu şirketlerin elinde olduğu belirtilmektedir. Az sayıda büyük şirket, küresel gıda değer zincirlerini yönetmektedir. Tohum ve gübre gibi girdilerden başlayarak, üreticiden ve aracılardan yapılan alımlardan tüketiciye satışa kadar uzanan zincir boyunca her aşamada şirketler fiyatları belirleyebilmektedir (Çaşkurlu, 2012: 172).

Bu çalışmada, Dünya Bankası (DB) ve Birleşmiş Milletler (BM) gibi uluslararası düzenleyici kurumların raporlarının yanında spesifik olarak sınır ötesi tarım arazilerine yapılan yatırımları izleyen ve raporlayan uluslararası sivil nitelikli kuruluşlar olarak ön plana çıkan Land Matrix, GRAIN ve OXFAM (Oxford yoksullukla mücadele komitesi) tarafindan üretilen araştırmalardan da yararlanılmıştır.

\section{Sınır Ötesi Tarım Yatırımları}

\subsection{Sinır Ötesi Tarım Yatırımı Kavramı}

Sınır ötesi tarım yatırımı kavramını; başka bir ülkenin sınırları içerisindeki toprağın tarımsal üretim yapmak için kiralanması veya satın alınması olarak tarif etmek mümkündür.

Nüfus artışı, küresel düzeyde yaşanan iklim değiş̧iklikleri, tarım arazilerinin tarım dışı amaçlar için kullanılması gibi faktörler, dünyada kişi başına düşen ekilebilir tarım arazisi miktarının azalmasına yol açmaktadır. Ülkeler, nüfusun beslenme ihtiyacını karşılamak için başka ülkelerin sınırları içindeki toprağın tarımsal üretim amacıyla kiralanması veya satın alınması yönünde girişimlerde bulunmaya başlamışlardır. 


\subsection{Sinır Ötesi Tarım Yatırımı ve Gelişimi}

Nüfus artışı ve beslenme düzenindeki değişikliklerin etkisiyle küresel gıda talebindeki artış, tarım arazileri ile tatlı su kaynakları üzerindeki baskıyı artırmaktadır (Rulli vd., 2013:1).

Sınır ötesi tarım yatırımları hakkında doğru ve kesin bir bilgiye ulaşmak, genellikle bu tür sözleşmelerin yüksek düzeyde gizliliğinden dolayı oldukça güçtür (Messerli vd., 2014:449). Bu durumun birinci nedeni, tarım arazilerini sınır ötesi yatırımcılara açan az gelişmiş ülkelerin doğru ve güvenilir bir veri kayıt sistemine sahip olmamasıdır. İkinci önemli nedeni ise, sınır ötesi tarım yatırımı yapan ülkelerin veya şirketlerin yaptıkları yatırımlarla ilgili bilgileri kamuoyuyla paylaşmamalarıdır.

Environmental Research Letters dergisinde 2014 yılında yayınlanan bir araştırmaya göre; günümüzde en az 126 ülkenin küresel tarıma elverişli arazileri satın aldığı/kiraladığı ya da sattığı/kiraya verdiği tahmin edilmektedir. En etkin müşteri ve yatırımcıların; ABD, Çin, İngiltere, Almanya, Hindistan ve Hollanda olduğu, yatırımcıların genellikle Güney Amerika, Afrika, Asya, özellikle de Brezilya, Etiyopya, Filipinler, Sudan, Madagaskar, Mozambik ve Tanzanya'da tarım arazisi aramakta olduğu belirtilmektedir (Vox, 2014).

Sınır ötesi tarım yatırımı yapılan bölgelerin başında Afrika kıtası gelmektedir. Yatırımcıların Afrika kıtasını seçmelerinin üç nedeni bulunmaktadır. Birincisi, ekilmemiş, boş ve nispeten ucuz olan geniş arazilerin varlığı; ikincisi; kırılgan, zayıf ve şeffaf olmayan yönetim sistemlerinin varlığı, üçüncüsü ise; ucuz işgücü imkanının olmasıdır (Deininger vd., 2011: 70).

Dünyadaki tarımsal arazi ticaret ağı haritası incelendiğinde dünyanın her tarafindan Afrika kitasındaki arazilere doğru bir hareket olduğu görülmektedir (Vox, 2014).

Dünyadaki küresel tarımsal ticaret ağı incelendiğinde Çinli yatırımcıların 33 farklı ülkede, ABD'li yatırımcıların 28 farklı ülkede ve İngiliz yatırımcıların 30 farklı ülkede tarıma elverişli arazi satın aldığı (ithalat), Etiyopya'nın topraklarını 21 farklı ülkeden, Sudan ve Madagaskar'ın ise 18 farklı ülkeden yatırımcılara sattığ (ihracat) görülmektedir. Topraklarını kiraya veren veya satan ülkeler genellikle ülke yönetiminin şeffaflıktan uzak, halkın katılımına kapalı, sağlıklı bir veri ve kayıt sisteminin bulunmadığı Sahra Altı Afrika'da yer alan az gelişmiş ülkelerdir (Vox, 2014).

DB’nin 2016 yılı verilerine göre; Çin, dünya nüfusunun yaklaşık yüzde 19'una sahip iken, dünyadaki tarım arazilerinin yalnızca yüzde 11'ine sahiptir. Çin, vatandaşlarının gıda ihtiyacını karşılayabilmek için başka ülke sınırları içerisindeki toprağı tarımsal üretim yapmak amacıyla kiralamak veya satın almak zorundadır. Nüfus ile ekilebilir tarım arazileri arasındaki bu dengesizlik Çin'i bu arayışlara sevk etmiştir. Bu nedenle Çin, son yıllarda başta Afrika kıtasındaki ülkeler olmak üzere birçok ülkede tarımsal üretim amacıyla toprak kiralama veya satınalma yönünde yatırımlar yapmaya başlamıştır. 
Sinır Ötesi Tarım Yatırımlarının Geleceği ve Ülkelerin Sinır Ötesi Tarım Yatırımı İhtiyacının Tespiti İçin Bir Yaklaşım

\subsection{Sinır Ötesi Tarım Yatırımını Zorunlu Kılan Faktörler}

İklim değişikliği, kişi başına düşen ekilebilir arazilerin azalması ve su kaynaklarının yetersizliği dünyadaki sınır ötesi tarım yatırımlarını zorunlu kılan faktörlerin başında gelmektedir.

\subsection{1. İklim Değişiklikleri}

Fosil yakıtların kullanımının artması, sanayi süreçleri, arazi kullanımındaki değişiklikler ve ormansızlaşma gibi faaliyetler, sera gazlarının atmosferdeki birikimleri sanayi devriminden beri hızla artmakta ve doğal sera etkisi kuvvetlenmektedir. Sera etkisinin en önemli ve açı etkisi, Yerküre'nin enerji dengesi üzerinde ek bir pozitif ışınımsal zorlama oluşturarak, Yerküre iklimini 1sıtmasıdır. 1906-2005 döneminde küresel ortalama yüzey sicaklıklarında gözlenen artış, $0.74{ }^{\circ} \mathrm{C}$ 'dir. Sera gazlarının atmosferik birikimlerindeki artışların, sıcaklık, yağış, nem, rüzgar gibi değiş̧kenlerde bölgesel ve küresel değişikliklere yol açması beklenmektedir (Türkeş, 2008: 26).

Dünyanın bugüne kadar karşılaştığı en ciddi tehlikelerin başında küresel düzeyde yaşanan iklim değişikliği gelmektedir. Yeryüzündeki hayatın kaynağı olan güneş ışınlarının bir kısmı atmosferden, bir kısmı da yeryüzünden geri yansımaktadır. İnsanların faaliyetleri nedeniyle atmosferde biriken sera gazları bu işleyişi bozacak bir etki oluşturmaktadır. Normal atmosfer koşullarında geri yansıyan bu 1şınların, atmosferden geçerken biriken sera gazları tarafindan emilerek dünyamızın fazladan 1sınmasına sebep olmasına sera etkisi denilmektedir. Işınların atmosferden geçerek yeryüzüne ulaşması veya yeryüzünden yansıdıktan sonra atmosferin içinde bulunan sera gazları tarafından emilimi mümkündür. Bu nedenle atmosferdeki sera gazı miktarındaki bir birimlik artış, sera etkisine yol açan bu ışınların emilerek atmosfer içinde tutulması olasılığında iki birimlik artışa neden olmaktadır (Tutulmaz, 2012: 604).

Mevsimlere göre ortalama sicaklık her geçen yıl artmaktadır. Küresel düzeyde yaşanmakta olan iklim değişikliğinin birçok nedeni vardır. Bilim insanları iklim değişikliğini çoğunlukla atmosferde biriken sera gazı miktarının artışına bağlamaktadırlar. Fosil yakıtlar (kömür, petrol, gaz) kullanan fabrikalar ile endüstriyel tarım yapan çiftçiler havaya karbondioksit salmakta, tarımsal üretimde kullanılan kimyasal gübreler havaya diazot monoksit gazı yaymakta, fabrikasyon yöntemiyle üretilen hayvanlar, havaya metan gazı salmaktadır. Böylece 1S1 miktarının artması daha fazla suyun buharlaşmasına neden olmaktadır. Bu yeni ekosistem, tropikal bölgelerde yağış miktarını artırırken, az yağı̧s alan bölgelerde yağış miktarının daha da azalmasına ve dolayısıyla bu bölgelerde yaşayan canlıların göç etmek zorunda kalmasına neden olmaktadır. Tüm bunların en önemli sonucu ise iklim istikrarsızlaşmaktadır (Aysu, 2015: 128).

İklim değişikliğinin en önemli sonuçlarının başında dünyadaki ortalama sıcaklık düzeyinin artması gelmektedir. Buna bağlı olarak buharlaşma artmakta, buharlaşan su daha fazla yağmura, sele ve toprak kayması gibi doğal afetlere yol açmaktadır. Buharlaşma, kutuplardaki buzulların erimesini de hızlandırmaktadır. 
Bütün bunların bir sonucu olarak tarımsal üretim yapılan alanlar azalmakta ve en önemlisi tarımsal üretim önceki yıllarla mukayese edilemeyecek kadar zorlaşmaktadır.

Sera gazı salınımlarının bugünkü düzeyinde ya da üzerinde devam etmesi, daha fazla 1sınmaya ve büyük olasılıkla iklim sisteminde 21. yüzy1l süresince 20 . yüzyılda gözlenenden daha büyük düzeylerde olabilecek birçok değişikliğe neden olacaktır. İnsan kaynaklı 1sınma ve deniz seviyesi yükselmesi, sera gazı birikimleri belirli bir düzeyde durdurulsa bile, iklim süreçleri ve geri beslemeleri ile bağlantılı zaman ölçeklerinin çok değişik ve uzun olması yüzünden, yüzyıllarca sürebilecektir (Türkeş, 2008: 36).

1.3.2. Kişi Başına Düşen Ekilebilir Tarım Arazilerinin Azalması

Gelişmiş ülkelerdeki tarım arazilerinde kullanılan kimyasallar toprağın kalitesini düşürerek verimliliğinin azalmasına yol açmıştır. Ayrıca tarım arazisi için kullanılması gereken topraklar yanlış arazi kullanımı, hatalı kalkınma politikaları, tarım alanlarının yerleşime açılması veya sanayi tesisi için kullanılması, fosil yakıtlardan kaynaklanan asit yağmurları, sanayi, maden, evsel ve nükleer atıklardan dolayı toprağın kirlenmesi, orman alanlarının çeşitli nedenlerle tahrip edilmesi ve yanlış tarımsal uygulamalar nedeniyle ve tarım dışı amaçlarla kullanılmaya başlanmıştır. Bu nedenle gıda ürünü elde etmek için kullanılması gereken tarım arazilerinin alanı daralmaktadır (Gülersoy, 2014: 73$84)$.

Bunların dışında, nüfusun hızla artması, insanların refah seviyesinin yükselmesi, küreselleşmeyle birlikte yaygınlaşan neoliberal politikaların etkisiyle tüketim alışkanlıklarının değişmesi gibi etkenler kişi başına düşen ekilebilir tarım arazilerinin hızla azalmasına yol açmaktadır. Buna karşın tarım arazilerinin genişletilebilmesi için çok az alan mevcuttur. Hâlihazırda, dünya toprak alanının yaklaşık yüzde 12 'si (1,5 milyar hektar) tarım ürünleri üretmek için kullanılmaktadır. Dünya tarım üretimi, son 50 yılda her y1l ortalama yüzde 2 ila yüzde 4 arasında büyürken, ekili alan (daimi ekim alanı ve ekilebilir arazi) yılda sadece yüzde 1 oranında büyümüştür (FAO, 2013: 10).

1.3.3. Su Kaynaklarının Yanlış - Bilinçsiz Kullanımı

Dünya yüzeyinin dörtte üçü suyla kaplıdır. Tuzlu deniz suyu, toplam suyun yüzde 97'sini oluşturmaktadır. Buz halindeki tatlı su yüzde 2, kullanılabilir tatlı su miktarı ise yüzde 1 civarındadır. Tatlı su miktarının yüzde 1'inden azı akarsulardan oluşmaktadır. Endüstriyel tarımın yaygınlaşmasıyla tarımsal üretimde su kullanımı oldukça artmıştır. 1940'larda dünyadaki su tüketimi yaklaşık 1.000 km³/yıl iken bu rakam 1960'larda iki katına çıkmıştır. 1990'larda ise endüstriyel ürün üretimiyle suyun kullanımı $4.130 \mathrm{~km}^{3} / \mathrm{y} 1 \mathrm{la}$ ulaşmıştır (Aysu, 2015: 129-220-223).

1.4. Dünyadaki Sınır Ötesi Tarım Yatırımları ve Küresel Aktörler

Dünya genelinde sınır ötesi tarım yatırımıyla ilgili Dünya Bankası (DB), Birleşmiş Milletler (BM), Avrupa İstatistik Ofisi (EUROSTAT) ve Ekonomik Kalkınma ve İşbirliği Örgütü (OECD) gibi uluslararası rapor ve araştırma 
Sinır Ötesi Tarım Yatırımlarının Geleceği ve Ülkelerin Sinır Ötesi Tarım Yatırımı İhtiyacının Tespiti İçin Bir Yaklaşım

yayınlayan kaynaklarda bile teknik ve detaylı bir rapor veya analiz mevcut değildir. Ancak akademik referans noktasında ikinci derece kaynak olarak değerlendirilebilecek sivil nitelikli bazı kuruluşlar, bu konuyla ilgili düzenli rapor ve araştırmalar yayınlamaktadırlar. $\mathrm{Bu}$ kuruluşların başında Land Matrix, GRAIN ve OXFAM gelmektedir.

Son yıllarda genişleyen şehirler, çeşitlenen madenler, altyapı projeleri ve gıda fiyatlarındaki artışlar geçmiş yıllarla mukayese edildiğinde tarım arazilerini kârlı bir yatırım aracı haline getirmiştir. Suudi Arabistan'ın su kıtlı̆̆ı, Çin'in değişen beslenme alışkanlıkları ve Avrupa Birliği’nin tarım arazilerini biyoyakıt için kullanıma açması gibi gelişmeler tarım arazilerinin önemini daha da artırmıştır. $\mathrm{Bu}$ nedenle sınır ötesi tarım arazilerinin kiralanması veya satın alınması işi son 15 yılda büyük bir ivme kazanmıştır (Toprak Atlası, 2015: 42).

2008 yılında yaşanan küresel gıda krizi ekonomik olarak güçlü devletlerin ve şirketlerin, tarım sektörünün önemini daha iyi kavramalarını sağlamıştır. Temel besin kaynaklarının serbest piyasada herhangi bir mal veya hizmet gibi işlem görmesinin tehlikeli ve kontrol edilemez sonuçlar doğurabileceğini gören gelişmiş ülkeler ve küresel şirketler, uluslararası ticarete konu olacak şekilde büyük arazi yatırımlarına yönelmişlerdir. 2008 öncesinde, tarımsal üretime yönelik olarak başka ülke sınırları içerisinde yılda ortalama 4 milyon hektarın altında arazi satın alınırken, sadece 2008 yılı ortasından 2009 yılı ortasına kadar geçen bir yıllık sürede dünya ölçeğinde 45 milyon hektardan fazla tarım arazisi sınır ötesi tarım yatırımı çerçevesinde el değiştirmiş̧tir (Kutluay ve Turhan, 2012: $34)$.

Uluslararası Arazi Koalisyonu (ILC)'nun 2011 yılında yayınladığ 1 raporda; 2000-2010 yılları arasında toplam 203 milyon hektar arazinin, satın alma veya uzun vadeli kiralama yoluyla uluslararası yatırımcıların kontrolüne geçtiği belirtilmektedir (Gülersoy ve Girgin, 2017: 147).

Gıda temini için hayati derecede önem taşıyan sınır ötesi tarım yatırımları, yalnızca uluslararası şirketler tarafından değil devletler tarafindan da yapılmaktadır. Örnek olarak; DB'nin 2016 yılı verilerine göre dünya nüfusunun yaklaşık yüzde 19'una, dünyadaki tarım arazilerinin ise yalnızca yüzde 11'ine sahip olan Çin, vatandaşlarının gıda ihtiyacını karşılayabilmek için sınır ötesi yatırımlarına büyük önem vermekte ve bu alanda büyük yatırımlar yapmaktadır. The Economist dergisinde yer alan değerlendirmeye göre; Çin'in son 12 yılda tarım sektörüne yönelik doğrudan yurt dışı yatırımlarının yüzde 36 oranında arttığ 1 ifade edilmektedir (Donat, 2017). Çin hükümeti, Çin-Afrika kalkınma fonu aracılığıyla önümüzdeki 50 yıl içinde Çin menşeli şirketlere Afrika kıtasında yatırım yapması için 5 milyar dolarlık bir taahhütte bulunduğunu açıklamıştır (Allafrica, 2008).

Sınır ötesi tarım yatırımı yapılan en önemli 11 hedef ülkede yaşanan arazi transferlerinin büyüklüğü ve yatırımcıların menşei incelendiğinde genel olarak, kuzey yarımkürede yer alan ülkelerin, güney yarımkürede yer alan ülkelerin arazilerine yatırım yaptığı görülmektedir (Toprak Atlası, 2015: 39). 
Uluslararası Tarım Arazilerine yapılan yatırımları izleyen ve raporlayan bir başka kuruluş olan Land Matrix' in 2016 yılı verilerine göre; dünya genelinde 1.549 adet (arazi büyüklüğü 85,5 milyon hektar) sınır ötesi tarım yatırımı anlaşması kayıt altına alınmıştır. Bu anlaşmaların 1.204'ü (yüzde 78) olumlu neticelenmiş, 212'sinin (yüzde 14) görüşmeleri devam etmekte, 97'si (yüzde 6) olumsuz neticelenmiş, 36'sı (yüzde 2) hakkında ise herhangi bir sonuç bilgisi bulunmamaktadir (Land Matrix, 2016: 7).

Tablo 1: Sınır Ötesi Tarım Arazilerinin Kullanım Amacına Göre Dağılımı (2016)

\begin{tabular}{|l|c|c|}
\hline \multicolumn{1}{|c|}{ Amaç } & $\begin{array}{c}\text { Kullanım Amacına Göre } \\
\text { Sözleşme Sayıları }\end{array}$ & $\begin{array}{c}\text { Toplam Sözleşme } \\
\text { Büyüklüğ̈̈ } \\
\text { (Milyon Hektar) }\end{array}$ \\
\hline Tarım & 1.403 & 24,1 \\
\hline Biyoyakıt & 221 & 5,1 \\
\hline Gıda Ürünleri & 553 & 9,2 \\
\hline Hayvancılık & 130 & 2,0 \\
\hline Gıda Dışı Tarımsal Ürünler & 236 & 2,3 \\
\hline Tasnif Edilmemiş & 263 & 5,6 \\
\hline Ormancılık & 187 & 12,0 \\
\hline Turizm & 25 & 1,7 \\
\hline Sanayi & 33 & 0,4 \\
\hline Koruma & 20 & 1,4 \\
\hline Yenilenebilir Enerji & 57 & 0,9 \\
\hline Diğgr Amaçlar & 28 & 1,0 \\
\hline Bilgi Mevcut Değil & 30 & 1,0 \\
\hline Toplam & $\mathbf{1 . 7 8 3}$ & $\mathbf{4 2 , 5}$ \\
\hline
\end{tabular}

Kaynak: Land Matrix 2016, International Land Deals for Agriculture. s.10.

Arazinin kullanım amacına göre dağılımı incelendiğinde, 24,1 milyon hektar ile tarım ilk sırada, 12 milyon hektar ile ormancılık ikinci sırada, 1,7 milyon hektar ile turizm üçüncü sırada yer almaktadır. Tarımın alt dalları incelendiğinde yüzde 38 (9,2 milyon hektar) ile gida ürünleri ilk sırada, yüzde 21 (5,1 milyon hektar) ile biyoyakıt üretimi ikinci sırada gelmektedir (Tablo 1).

Tablo 2: Kıtalara Göre Arazi Kullanım Amaçları Dağılımı (Alanın \% 'Si - 2016)

\begin{tabular}{|l|c|c|c|c|c|c|}
\hline Arazi Kullanım Amacı & Afrika & Avrupa & Amerika & Asya & Okyanusya & Dünya \\
\hline Biyoyakıt & $32 \%$ & $1 \%$ & $29 \%$ & $16 \%$ & $16 \%$ & $21 \%$ \\
\hline Gıda Bitkileri & $39 \%$ & $44 \%$ & $50 \%$ & $21 \%$ & $30 \%$ & $39 \%$ \\
\hline Hayvancılık & $3 \%$ & $17 \%$ & $16 \%$ & $1 \%$ & $11 \%$ & $8 \%$ \\
\hline Gıda Dışı Tarımsal Ürünler & $9 \%$ & $1 \%$ & $1 \%$ & $29 \%$ & $3 \%$ & $9 \%$ \\
\hline Tarım (Sınıflandırılmamış) & $17 \%$ & $37 \%$ & $4 \%$ & $33 \%$ & $40 \%$ & $23 \%$ \\
\hline
\end{tabular}

Kaynak: Land Matrix 2016, International Land Deals for Agriculture. s. 11.

Kıtalara göre arazi kullanım amaçları incelendiğinde, Biyoyakıt amaçlı kullanımda sırasıyla Afrika, Amerika, Asya ve Okyanusya kıtaları gelmektedir. Amerika kıtasında ve Avrupa kıtasında neredeyse alanın yarısını gıda bitkileri 
Sinır Ötesi Tarım Yatırımlarının Geleceği ve Ülkelerin Sinır Ötesi Tarım Yatırımı İhtiyacının Tespiti İçin Bir Yaklaşım

oluşturmaktadır. Asya ve Okyanusya kıtasında sınıflandırılmamış tarım ürünleri en fazla yatırım yapılan alanı oluşturmaktadır(Tablo 2).

Dünya genelinde 2008 yılında yaşanan küresel gida krizinden sonra sınır ötesi tarım sözleşmelerinin sayısında hızlı bir artış yaşanmıştır. Örneğin; 2007 yılında bir yılda imzalanan sınır ötesi sözleşme sayısı 200'ün altında iken bu sayı 2016 yılında dört kattan fazla artarak 800'ün üzerine çıkmıştır (Land Matrix, 2016: 13).

\subsubsection{Yatırim Fonlart}

Sınır ötesi tarım yatırımı yapan aktörlerin başında ABD'li yatırım bankaları Goldman Sachs ve Morgan Stanley, İngiliz Landkom şirketi ile Japon Mitsui şirketleri gelmektedir. Son 5 yılda Goldman Sachs Çin'de hayvancılık alanında yatırım yaparken, Morgan Stanley tarım ürünleri üretmek için Ukrayna'da 40 bin hektarlık tarım arazisi satın almıştır. İngiliz şirketi Landkom Ukrayna'da 100 bin hektarlık bir arazi kiralayarak bu arazide gıda ve biyoyakıt için üretim yapmaya başlamıştır. Japon şirketi Mitsui ise Brezilya'da 100 bin hektar büyüklüğündeki bir arazide soya fasulyesi üretmeye başlamıştır (Donat, 2014).

'Hedge' fonlar (riskten korunma) ve bankalar ucuz tarım arazilerinin yoğun olarak bulunduğu bölgelere yatırım yapmaya başlamışlardır. Örneğin; ABD'li yatırım fonu Black Rock tarafindan tahsis edilen 200 milyon dolarlık bir spekülatif fonun 30 milyon dolarlık kısmı tarım arazisi satın almak için ayrılmıştır. Rusya'nın en büyük hububat üreticilerinden biri olan Black Earth Farming adlı fonun patronu Mikhail Orlov "Bu işte akıllı davranan tahıl değil, para hasat eder" mesajı ile sektörün önemine dikkat çekmektedir. Global Farming Ltd. adlı fon, yatırımlarının geri dönüş süresinin 6 ila 8 yıl gibi kısa bir süre olduğunu öngörerek tarım ve hayvancılık yapmak üzere 1,2 milyon hektar tarım arazisi satın almaya karar vermiştir. Barclays, Deutsche Bank, UBS, Morgan Stanley gibi büyük bankalar da tarım arazilerine yatırım yapmaya başlamıştır. GRAIN'in tahminlerine göre, üçüncü ülkelerde tarım arazisi sahibi fon sayısı 120'yi aşmış bulunmaktadır (Sarpkaya, 2010).

Yatırım fonları özellikle 2008 gıda krizinden sonra arazi edinimi konusunda önemli bir aktör olarak tarım sektöründe boy göstermeye başlamıştır. Yatırım fonları tarafından yapılan sözleşmelerin kıtalara göre dağılımı incelendiğinde yatırım fonlarının toplam arazi yatırımı içindeki payının yüzde 9 civarında olup ağırlıklı olarak Avrupa, Asya ve Amerika kıtasında yatırım yaptıkları, Afrika kıtasına ise ilgi göstermedikleri görülmektedir (Land Matrix, 2016: 29).

\subsection{2. Çok Uluslu Şirketler}

Çok Uluslu Şirket (ÇUŞ), toplam maddi kaynaklarının en az yüzde 20'si dış ülkelerde olan ve kârlarının en az yüzde 35'ini uluslararası faaliyetlerden elde eden şirketler demektir. ÇUŞ'lar gelişmemiş ülkelerde bulunan tarım arazilerine ilgi duyan önemli bir aktördür. ÇUŞ’ların son yıllarda sınır ötesi tarım arazilerine büyük yatırım yaptıkları görülmektedir (Artisien,1985: 5). 
Küreselleşme ile birlikte ülkeler arasındaki sosyal, ekonomik ve kültürel ilişkilerin yakınlaşması ve hız kazanması, uluslararası ticaretin serbestleşmesi yönündeki girişimler, ekonomik entegrasyonun da artmasıyla ÇUŞ'ların global düzeyde güçlü birer aktör olarak sahneye çıkmalarına zemin hazırlanmıştır.

20. yüzyıla girerken birçok ülkenin, savaşlar ve sömürgeci baskılar nedeniyle sınırları değişmiştir. Fakat 1990'ların başından itibaren Dünya Ticaret Örgütü (DTÖ)'nün getirdiği düzenlemeler ile tarım ürünleri ticaretinde yaşanan serbestleşme ve artan küreselleşme nedeniyle ulusal sınırların önemi azalmıştır. Dünyanın her tarafında bulunan yaygın şube ağı ve milyonlarca ton ürünü yöneten lojistik güçleriyle Bunge, Cargill, Louis Dreyfus ve ADM gibi şirketler tarım ürünlerini, üretildikleri bölgelerden alarak önce işlenecekleri yere, sonra da tüketilecekleri yerlere taşımak için gerekli ulaşım ağını kurmuşlardır (Toprak Atlas1, 2015: 14).

Tablo 3: Fortune Global 500 listesindeki tarım şirketleri (2015)

\begin{tabular}{|c|l|c|}
\hline $\begin{array}{c}\text { Fortune Global 500 } \\
\text { Sirası }\end{array}$ & Şirket Adı & $\begin{array}{c}\text { Gelir } \\
\text { (milyon USD) }\end{array}$ \\
\hline 11 & Berkshire Hathaway & 210.821 \\
\hline 112 & Archer Daniels Midland & 67.702 \\
\hline 127 & PepsiCo & 63.056 \\
\hline 157 & Louis Dreyfus & 66.733 \\
\hline 185 & JBS & 48.870 \\
\hline 187 & Dow Chemical & 48.778 \\
\hline 194 & Caterpillar & 47.011 \\
\hline 206 & Coca-Cola & 44.294 \\
\hline 214 & Bunge & 43.455 \\
\hline 235 & Tyson Foods & 41.373 \\
\hline 254 & Wilmart International & 38.777 \\
\hline 299 & CHS & 34.582 \\
\hline 352 & Mondelez International & 29.636 \\
\hline 364 & Deere and Co. & 28.863 \\
\hline 379 & DuPont & 27.940 \\
\hline & & $\mathbf{8 4 1 . 8 9 1}$ \\
\hline
\end{tabular}

Kaynak: http://beta.fortune.com/global500/, (20.07.2018)

Tablo 3'e göre 2015 y1lı Fortune Global 500 listesinde yer alan tüm şirketlerin toplam geliri 27,6 trilyon ABD Doları, kârları ise 1,5 trilyon ABD Doları olarak gerçekleşmiştir. Global 500 listesinde yer alan tarım şirketlerinin toplam ciro içindeki payı yüzde 3 olarak gerçekleşmiştir (Tablo 3).

Günümüzde uluslararası ticaret, ÇUŞ'lar tarafından yönetilir hale gelmiştir. Bu şirketler yerel gıda sistemlerini de kontrol altına almak için çok büyük yatırımlar yapmaktadır. Örnek olarak, dünyadaki toplam nüfusun yüzde 5'i, içme suyunu ÇUŞ'lardan satın almaktadır. Bu şirketlerin yıllık geliri dünya petrol ticaretinin yıllık gelirinin yarısına eşittir. Bu şirketler, tüketicileri kendileri tarafından denetlenebilen gıdaları almaya yönlendirmektedirler. ÇUŞ’lar eliyle 
Sinır Ötesi Tarım Yatırımlarının Geleceği ve Ülkelerin Sinır Ötesi Tarım Yatırımı İhtiyacının Tespiti İçin Bir Yaklaşım

tarım ürünleri piyasasının kuralları yeniden belirlenmektedir. $\mathrm{Bu}$ nedenle insanların yeterli, güvenilir, sağlıklı ve ekolojik olarak sürdürülebilir bir şekilde üretilmiş gıdaya ulaşmaları her geçen gün daha da zorlaşmaktadır (Aysu, 2008: 226).

Finansal raporları incelendiğinde, ÇUŞ'ların birçok dünya devletinden daha güçlü bir ekonomiye sahip oldukları görülecektir. DB verilerine göre 2015 yılında dünyadaki en büyük 100 ekonomiden 69'u şirket, geri kalan 31 'i ise devlettir. (Worldbank, 2016). Şirketler, ekonominin belirleyici unsuru haline gelmişlerdir. 2017 yılı finansal verileri kullanılarak aynı yöntemle sıralama yapıldığında ülkelerin ve şirketlerin kendi içindeki sıralaması değiş̧tiği halde en büyük 100 ekonomi içinde şirketlerin sayısı 2015 yılında olduğu gibi 69, ülkelerin sayısı ise yine 31 olarak gerçekleşmiştir (Fortune Global 2017 ve The World Factbook 2018).

\section{Sınır Ötesi Tarım Yatırımının Etkileri ve Sonuçları}

Ülkeler, iç talebin gıda ihtiyacını karşılamak veya ticari değeri yüksek gıda ürünlerinin ticaretinden gelir elde etmek amacıyla sınır ötesi tarım ticaretine yönelmektedir. Sınır ötesi tarım yatırımının etkilerini ve sonuçlarını tarım arazilerine yatırım yapan ve tarım arazilerini kiraya veren ülkeler açısından değerlendirmek mümkündür. Sınır ötesi tarım yatırımlarının etkisi ve sonuçları genel olarak değerlendirildiğinde, topraklarını tarımsal üretim için yabancı yatırımlara açan ülkelerin daha fazla etkilendiği görülmektedir. Özellikle sınır ötesi tarım yatırımlarının olumlu ve olumsuz sonuçları açısından değerlendirme yapıldığında yatırım yapan ülkelerin daha ziyade olumlu etkilendiği, yatırım yapılan ülkelerin ise daha ziyade olumsuz etkilendiği görülmektedir.

2.1. Tarım Arazilerine Yatırım Yapan Ülkeler Açısından Değerlendirilmesi

Son yıllarda hem özel sektörün hem de kamu sektörünün tarım arazilerine olan ilgisi artmaya başlamıştır. Tarla tarımına yönelik büyük ölçekli tarım arazisi kiralama veya satın alma dalgasının Afrika, Asya ve Latin Amerika'da yoğun olarak yaşandığı görülmektedir. Uzun vadede gıda ve enerji güvenliğini temin etmek için tarımsal emtia fiyatlarında yaşanan değişimler ve arazi fiyatlarındaki yükselmeler her geçen gün etkisini daha fazla hissettirmektedir (Rey, 2014).

Günümüzde sınır ötesi tarım arazilerine en çok yatırım yapan ülkelerin başında ABD, Malezya, Singapur, Birleşik Krallık, Birleşik Arap Emirlikleri, Çin, Hindistan, Brezilya, Kanada ve Hollanda gelmektedir. Bu ülkelerin yatırım yaptığı hedef ülkeler ise Brezilya, Sudan, Mozambik, Ukrayna, Kongo, Papua Yeni Gine, Rusya Federasyonu, Endonezya, Demokratik Kongo Cumhuriyeti ve Guyana'dir (Land Matrix, 2016: 22).

Land Matrix'in verilerine göre; 2010-2016 dönemlerinde yabancı bir ülkede tarım yatırımı yapmak için sözleşme imzalayan ilk 10 yatırımcı ülke Malezya, ABD, İngiltere, Singapur, Suudi Arabistan, Hollanda, Hindistan, Hong Kong, Çin ve Arjantin şeklinde sıralanmaktadır (Land Matrix, 2016: 23). 
Sınır ötesi tarım arazilerine yatırım yapan ülkelerin yatırım kararlarındaki en önemli etkenlerin başında, sahip oldukları tarım arazilerinin nüfusu beslemek için yetersiz kalması, toprak kalitesinin düşük olması, işgücü maliyetlerinin yüksek olması, hammadde ve pazara olan mesafenin uzak olması ve kaynakları uzun vadede elde tutmak gibi nedenler olarak siralamak mümkündür.

Tarım ürünlerini sınır ötesi topraklarda yatırım yaparak karşılayan ülkeler için en önemli risklerin başında, yatırım yapılan ülkelerdeki istikrarsız yönetimler, ülke yönetiminde sıklıkla yaşanan değişiklikler, en temel ürün olan gıda ürünlerinde dış ülkelere bağımlı hale gelinmesi ve uzun dönemde sınır ötesi tarım yatırımlarında meydana gelebilecek maliyet artışları ve belirsizliklerin kontrol edilememesi gelmektedir.

\subsection{Tarım Arazilerini Kiraya Veren Ülkeler Açısından Değerlendirilmesi}

Land Matrix'te yer alan değerlendirmeye göre; büyük ölçekli arazi edinimlerinin hedef bölgelerde yaşayan insanların geçim kaynakları üzerindeki etkileri ülkeden ülkeye ve bölgeden bölgeye büyük farklılıklar göstermektedir. Bununla birlikte, Afrika, Asya, Doğu Avrupa, Orta ve Güney Amerika'da 21 ülkede 66 vakayı kapsayan 44 bilimsel araştırmanın meta-analizi, yapılmıştır. Analiz sonucunda elde edilen bulgulara göre; geçim sıkıntısını olumsuz etkileyen konuların başında yüzde 24 ile araziye ve doğal kaynaklara erişimin zorluğu, yüzde 18 ile geçim kaynakları üzerinde artan anlaşmazlıklar ve yüzde 9 ile yerel halk nezdindeki artan eşitsizlik gelmektedir (Land Matrix, 2016: 39).

Yatırımcilar tarafindan kiralanan veya satın alınan arazilerde gıda ürünleri üretimi yüzde 28 ile ilk sırada, biyoyakıt amacıyla yapılan üretim yüzde 19 ile ikinci sırada, ağaç ve lif elde etmek için yapılan üretim yüzde 11 ile üçüncü sırada yer almaktadır (Gülersoy ve Girgin, 2017: 153).

Sınır ötesi tarım yatırımlarının yapıldığı bölgeler genellikle modern tarım tekniklerinin uygulanmadığı, geleneksel tarım yöntemlerinin yaygın olduğu az gelişmiş ülkelerdeki tarıma elverişli alanlardır. Sınır ötesi tarım yatırımlarının kırsal bölgelerde meydana getirdiği olumlu değişim, çiftçilerin refah seviyesinde meydana gelen artışlar, ilave istihdam imkânları ve halkın işsizlik nedeniyle şehirlere göç etmek zorunda kalmamaları şeklinde sıralanabilir.

Geniş tarım arazilerine sahip az gelişmiş ülkelerde geleneksel tarım yöntemleri ve üretim araçları ve teknikleri kullanılmaktadır. Az gelişmiş ülkelerde büyük tarım çiftliklerinin kurulmaya başlanması, modern tarım aletlerinin ve imkânlarının kullanılmasını zorunlu hale getirmiştir. Son dönemlerde, sıcaklık, nem, yağış gibi iklimin etkisini kontrol altına almak amacıyla, tarım tekniklerini içeren yeni teknolojiler büyük çaplı üretim yapılan tarımsal çiftliklerde kullanılmaya başlanmıştır.

Sınır ötesi tarım yatırımı yapan aktörlerin gelişmekte olan ülkelerin tarım sektörüne yatırım yapmaları, yoksulluğun azaltılarak genel refah seviyesinin yükseltilmesine imkan sağlayabilir. Ancak şeffaf yönetimlerin olmadığı az gelişmiş ülkelerde geniş arazilerin sınır ötesi tarım yatırımı yapan aktörler 
Sinır Ötesi Tarım Yatırımlarının Geleceği ve Ülkelerin Sinır Ötesi Tarım Yatırımı İhtiyacının Tespiti İçin Bir Yaklaşım

tarafindan tarımsal üretim amaciyla kiralanması veya satın alınması yerel üreticiler için büyük riskleri beraberinde getirmektedir (Liu, 2014: IV).

Bir ülkenin sınırları içerisinde toprağı başka bir ülkenin tarımsal üretim amacıyla kiralaması veya satın alması yerel halklar için toprak gaspı, mülkiyet sorunlarının baş göstermesi ve zorunlu nüfus göçlerinin meydana gelmesi gibi olumsuz sonuçların ortaya çıkmasına neden olmaktadır (Berstein, 2014: 58).

\subsubsection{Toprak Gasp1}

Toprak gasp1 terimi; ekonomik olarak varlıklı ancak gıda güvenliği olmayan ülkeler ile özel yatırımcılar tarafından, ihracata yönelik tarımsal ürünler üretmek amacıyla çoğunlukla az gelişmiş veya gelişmekte olan ülkelerde geniş arazilerin kiralanması veya satın alınması olarak tanımlanmaktadır (Daniel ve Mittal, 2009: 1).

Toprak gaspı terimi, daha önce BM Gıdaya Erişim Hakkı Özel Raportörü olarak görev yapmış olan Olivier De Schutter tarafindan; "Ekilebilir büyük arazilerin ev sahibi hükümetler ile yabancı yatırımcılar arasında gerçekleşen, geçinebilmek için buraları kullanmaya mecbur mahalli nüfusun pek az dahil olduğu ya da hiç dahil olmadığı müzakereler neticesinde el değiştirdiği küresel muhasara hareketidir" şeklinde tanımlanmıştır (De Schutter, 2011: 504).

Bazı bilim insanları tarafından toprak gaspı olarak nitelendirilen sınır ötesi tarım yatırımları belli amaçlar için yapılmaktadır. İlk sırada, gelecek dönemlerde gıda fiyatlarındaki dalgalanmalardan korunmayı hedefleyen ve artan nüfus için gıda ürünü ithal eden ülkelerin arazi talebi gelmektedir. İkinci sırada, küresel düzeyde tarım ürünleri ticareti yapan tüccarların, daha düşük üretim maliyetleri ve daha yüksek kar marjiyla daha fazla ülkede faaliyetlerini sürdürmek istemeleri gelmektedir. Üçüncü sırada ise arazi fiyatlarının yükselmesinden dolayı kazanç elde etmek isteyen finansal kuruluşların, enflasyon riskine karşı korunma ve uzun vadede tarımsal yatırımlardan kâr elde etme potansiyeli nedeniyle araziye yatırım yapmaları gelmektedir (Grant ve Das, 2015: 5).

Toprak Atlası'nda yer alan değerlendirmeye göre; dünya genelinde toprak gaspının yaşandığı bölgeler incelendiğinde, Afrika kıtasındaki az gelişmiş ülkelerinin bulunduğu bölgelerin, özellikle Sahra Altı Afrika bölgesinde yer alan ülkelerin bu durumdan çok fazla etkilendiği görülmektedir. Amerika kıtasında Güney Amerika bölgesi, Avrupa kıtasında Tuna ovasının etkisiyle Macaristan ve Romanya'nın da bulunduğu Orta ve Doğu Avrupa bölgesi, Asya kıtasında ise kuzey bölgeler ve Uzak Doğu Asya bölgesi toprak gaspının yaşandığı bölgeler olarak ön plana çıkmaktadır (Toprak Atlası, 2015: 74).

Ülkelerin ve küresel şirketlerin global düzeyde tarım arazilerine olan ilgilerinin artması, insan hakları ihlalleri ile bir çok çevresel sorunun ortaya çıkmasına neden olmaktadır. Toprak gaspı niteliğindeki tarımsal yatırımlar yoksul ve savunmasız nüfusun yerinden edilmesine, yoksulluğun artmasına ve gıdaya erişim imkânının güçleşmesine yol açmaktadır (Grant ve Das, 2015: 1). 


\subsubsection{Mülkiyet Sorunlart}

Sınır ötesi tarım yatırımlarının olumsuz etkilerinden birisi de mülkiyet sorunlarının ortaya çıkmasıdır. Sınır ötesi tarım yatırımına maruz kalan az gelişmiş ülkelerde sağlıklı bir veri kayıt sisteminin olmaması nedeniyle küçük aile işletmeleri tarafindan işletilen arazilerin mülkiyeti tapu kayıtlarında işleten ailelerin üzerinde görünmemektedir. $\mathrm{Bu}$ nedenle bu araziler devletin hazine arazisi gibi işlem görmekte, alış ve satış işlemleri de devlet tarafindan yapilmaktadir.

1942 yılında kurulan ve dünya genelindeki yoksulluğun azaltılması için mücadele eden Uluslararası Yardım Örgütü Oxfam'ın Almanya temsilciliğinden Marita Wiggerthale, kuşaklar boyu aynı aile tarafından ekilen, ancak tapuda kaydı olmayan bir arazinin günün birinde yabancı bir şirkete geçebileceğine dikkat çekmektedir. Wiggerthale'e göre; bu vakalarda çoğunlukla toprakları kullanma hakkı çiğnenmekte, tarım yapan aileler yerlerinden sürülmekte ve sonuçta tüm geçim kaynakları ellerinden alınmaktadır. Çiftçilerin üretim yaptıkları toprağın mülkiyetine sahip olmamaları bu toprağın günün birinde bir yatırımcıya verileceği tehlikesiyle karşı karşıya kalmalarına yol açmaktadır (Arbutina, 2011).

\subsubsection{Zorunlu Nüfus Göçleri}

Çin, Güney Kore, Körfez ülkeleri ve Hindistan gibi ülkelerden kamu ya da özel sektör yatırımcıları, gelişmekte olan ülkelerde satın alma veya uzun süreli kiralama anlaşmalarıyla sınır ötesi tarım arazilerine yatırım yapmakta, buralarda üretilen gıda maddeleri sadece yatırımı yapan ülkeye ihraç edilmektedir. Kiralanan veya satın alınan büyük arazilerde halk yerinden göç etmeye zorlandığı için en büyük zararı yine yerel halklar yaşamaktadır (Ricking, 2011).

Oxfam, Uganda'da zorunlu göçü temsil eden bir vakayı belgelemiştir. İngiliz bir yatırımcının Ugandalı yetkililer ile yaptığı anlaşma yüzünden, dev bir çam ve okaliptüs plantasyonuna yer açmak için 22 bin 500 kişi yaşadıkları yerleri terk etmek zorunda kalmıştır. Yerlerini terk etmek zorunda kalan bu çiftçilere önceden bilgi verilmemiş sonrasında da herhangi bir tazminat ödemesi yapılmamıştır (Arbutina, 2011).

\section{3. Ülkelerin Ekilebilir Tarım Alanları ve Sınır Ötesi Tarım Yatırımı İhtiyacının Tespiti İçin Bir Yaklaşım}

En fazla kişi başına ekilebilir tarım arazisi olan ilk 20 ülke incelendiğinde nüfusu kalabalık olan Brezilya, Fransa, Almanya, İtalya, İngiltere, Hindistan ve Çin gibi ülkeler ilk 20 dışında kalmıştır. Bu ülkelerde kişi başına düşen ekilebilir arazi miktarı Almanya'da 0,14 hektar, Hindistan'da 0,12 hektar, İtalya'da 0,11 hektar, İngiltere'de 0,10 hektar ve Çin'de 0,08 hektardır. Bu ülkeler, vatandaşının gıda ihtiyacını karşılayabilmek için başka ülkelerin sınırları içinde tarım arazisi kiralamak veya satın almak durumundadırlar (World Bank, 2019). DB'nin 2016 yılı verilerine göre en çok sınır ötesi tarım yatırımı çeken Sahra Altı Afrika bölgesinde kişi başına düşen ortalama ekilebilir tarım arazisi miktarı 0,21 
Sinır Ötesi Tarım Yatırımlarının Geleceğgi ve Ülkelerin Sinır Ötesi Tarım Yatırımı İhtiyacının Tespiti İçin Bir Yaklaşım

hektardır (World Bank, 2019). Bu rakam dünya ortalaması olan 0,19 hektarın biraz üzerindedir. Ancak tarım arazilerinin işlenmesinde modern üretim yöntemlerinin kullanılmaması, yağışın yeterli ve sıcaklığı yıl boyunca yüksek olması, küçük çiftlikler halinde işletmecilik yapılması ve belki de en önemli unsurların başında gelen ucuz işgücü ve ürün dağıtım alanına yakınlık gibi sebepler sınır ötesi tarım yatırımcılarının ilgilisinin bu bölgelere doğru kaymasına neden olmuştur.

FAO'nun 2030/2050 tahmin raporuna göre; gelişmekte olan ülkeler, gelişmiş ülkeler ve dünya geneli için kişi başına düşen (kullanımda olan) ekilebilir arazi miktarlarının her geçen yıl düştüğü tespit edilmiştir. Dünya nüfusu ve gidaya olan talep sürekli artarken kişi başına düşen ortalama ekilebilir tarım arazilerinin her yıl azalması, gelecek yıllarda ülkelerin gıda krizleriyle karşılaşma ihtimalinin çok yüksek olduğunu göstermektedir (FAO, 2012: 108).

Tarım Makinaları Birliği’nin 2017 yılı raporuna göre; dünyada kişi başına düşen işlenebilir tarım arazisi alanı, 1961'dan 2011 yılına kadar geçen 40 yıllık sürede yarı yarıya azalmıştır. Bu azalmanın en önemli nedeni 1960 yılında dünya nüfusu 3,1 milyar iken 2011 yılında 7 milyar olmasıdır (World Bank, 2020). Aynı dönemde ekilebilir alanların kapladığı alan ise yüzde 11 oranında (150 milyon hektar) artmıştır. Eğer tarım ürünlerine olan talep günümüzdeki gibi artmaya devam ederse 2050 y1lında 320-850 milyon hektar arasında ilave ekilebilir tarım arazisine ihtiyaç duyulacaktır. 320 milyon hektar Hindistan'ın yüzölçümüne, 850 milyon hektar ise Brezilya'nın yüzölçümüne karşıllık gelmektedir (Toprak Atlası, 2015: 15).

Tablo 4: Kullanimda Olan Toplam Ekilebilir Alan: Mevcut Veriler ve Gelecekteki Durum

\begin{tabular}{|c|c|c|c|c|c|c|c|}
\hline \multirow{2}{*}{ Veriler } & \multicolumn{4}{|c|}{$\begin{array}{l}\text { Kullanımdaki Ekilebilir Arazi } \\
\text { (Milyon Hektar) }\end{array}$} & \multicolumn{3}{|c|}{$\begin{array}{l}\text { Yıllık Büyüme } \\
\text { Oranları (Y1l / \%) }\end{array}$} \\
\hline & $\begin{array}{l}1961 \\
1963\end{array}$ & $\begin{array}{l}2005 \\
2007\end{array}$ & 2030 & 2050 & $\begin{array}{l}1961 \\
2007\end{array}$ & $\begin{array}{l}1991 \\
2007\end{array}$ & $\begin{array}{c}2005 / 07 \\
-2050\end{array}$ \\
\hline Dünya & 1.372 & 1.592 & 1.645 & 1.661 & $\mathbf{0 , 2 8}$ & $\mathbf{0 , 1 3}$ & $\mathbf{0 , 1 0}$ \\
\hline Gelişmiş Ülkeler & 678 & 624 & 608 & 586 & $-0,17$ & $-0,51$ & $-0,14$ \\
\hline Gelişmekte Olan Ülkeler & 693 & 968 & 1.036 & 1.075 & 0,65 & 0,60 & 0,24 \\
\hline Çin ve Hindistan Hariç & 427 & 668 & 734 & 775 & 0,74 & 0,70 & 0,34 \\
\hline Sahra altı Afrika & 133 & 240 & 266 & 291 & 0,83 & 1,25 & 0,44 \\
\hline Latin Amerika & 105 & 202 & 235 & 251 & 0,98 & 0,61 & 0,49 \\
\hline Yakın Doğu/Kuzey Afrika & 86 & 84 & 84 & 84 & 0,31 & $-0,17$ & 0,00 \\
\hline Güney Asya & 191 & 206 & 210 & 213 & 0,14 & 0,06 & 0,08 \\
\hline Doğu Asya & 178 & 236 & 241 & 236 & 0,93 & 0,87 & 0,00 \\
\hline
\end{tabular}

Kaynak: FAO, 2012: 109.

Ekilebilir arazinin genişletilmesi için yapılan tüm tahminler, ekilebilir alanın net genişlemesini ifade etmektedir. Tablo 4'teki veriler, Sahra Altı Afrika bölgesi, Latin Amerika ve Doğu Asya bölgesinde önemli bir tarımsal büyüme potansiyeli olduğunu göstermektedir. Ayrıca bir diğer önemli husus da, dünyada 
ekilebilir tarım arazilerinde 1961-1963 ve 2005-2007 tarihleri arasında gelişmekte olan ülkelerde 275 milyon hektarlık bir artış meydana gelirken gelişmiş ülkelerde 54 milyon hektarlık bir düşüş yaşanmış olmasıdır. Gelişmekte olan ülkelerde daha önce tarıma açık olmayan alanlar tarım için kullanıma aç1ırken, gelişmiş ülkelerde tarım alanlarının yoğun kullanılmasına bağlı olarak arazi verimliliğinin düşmesi nedeniyle bazı araziler tarımsal amaç dışında kullanılmaya başlanmıştır. Gelişmekte olan ülkelerdeki artış ve gelişmiş ülkelerdeki azalış birlikte değerlendirildiğinde dünya genelinde toplamda 220 milyon hektarlık bir genişleme olduğu görülmektedir (Tablo 4).

Nüfus artışı, tarım alanlarının tarım dışı amaçlarla kullanılması ve iklim değişikliği gibi nedenler ekilebilir tarım arazilerinin her geçen gün azalmasına yol açmaktadır. Ülkelerin sınır ötesi tarım yatırımı ihtiyacını ölçmek amacıyla, DB'nin 2016 yılı verileri esas alınarak ekonomik gelişmişlik açısından en büyük 20 ülke için tarım arazisi ihtiyacı/fazlası tablosu oluşturulmuştur. Ekonomisi en büyük olan 20 ülkenin toplam arazi miktarı, dünyadaki toplam arazi içindeki payı, toplam ekilebilir tarım arazisi, toplam arazisinin ekilebilir olan bölümü, nüfusu ve kişi başına düşen ekilebilir arazi miktarı baz alınarak bir tablo hazırlanmıștır (Tablo 5).

Bu tabloda (Tablo 5), DB tarafindan 2016 yılında yayınlanan en son veriler kullanılmıştır. Ülkelerin ekilebilir tarım arazileri ile nüfusları arasında bir ilişki kurularak bir ülkenin tarım arazisi ihtiyacı/fazlası hesaplanmaya çalışılmıştır. Dünyada kişi başına düşen ekilebilir arazi miktarı 0,19 hektar verisi referans alınarak 20 ülkenin sınır ötesi yatırım ihtiyacı tablosu oluşturulmuştur. Tablo 5 'in en sağ sütunundaki veri, ilgili ülkenin nüfusunun ne kadar fazlasının ihtiyacını karşılayabileceğini veya nüfusun ne kadarlık bir kısmının gıda ihtiyacını karşılamak için yatırımı yapması gerektiğini göstermektedir. 
Sınır Ötesi Tarım Yatırımlarının Geleceği ve Ülkelerin Sınır Ötesi Tarım Yatırımı İhtiyacının Tespiti İçin Bir Yaklaşım

Tablo 5: Ekonomik Büyüklük Açısında En Büyük 20 Ülkenin Ekilebilir Tarım Arazisi İhtiyacı Tablosu (2016)

\begin{tabular}{|c|c|c|c|c|c|c|c|c|c|c|}
\hline S.No & Ülke Adı & $\begin{array}{l}\text { Toplam } \\
\text { Arazi } \\
\text { Miktarı } \\
(\mathrm{km} 2)\end{array}$ & $\begin{array}{c}\text { Ülkedenin } \\
\text { Toplam } \\
\text { Arazisinin } \\
\text { Ekilebilir Kısmı } \\
\text { (\%) }\end{array}$ & $\begin{array}{c}\text { Ülkelerin Kişi } \\
\text { Başına Düşen } \\
\text { Ekilebilir Arazi } \\
\text { Miktarı (Hektar) }\end{array}$ & $\begin{array}{c}\text { Toplam } \\
\text { Ekilebilir } \\
\text { Tarrm Arazisi } \\
\text { Miktarı (km2) }\end{array}$ & Nüfus (2016) & $\begin{array}{l}\text { Kişi Başına Ekilebilir } \\
\text { Arazi Miktarının Dünya } \\
\text { Ort. Referans Kabul } \\
\text { Edilirse Mevcut Nüfus } \\
\text { için iDEAL Ekilebilir } \\
\text { Arazi Miktarı (km2) }\end{array}$ & $\begin{array}{l}\text { Fark (Arazi } \\
\text { Büyüklüğgu } \\
\text { km2) }\end{array}$ & $\begin{array}{c}\text { Ülkenin Mevcut } \\
\text { Ekilebilir Arazi } \\
\text { Miktarı ile } \\
\text { Bakabileceği ilave } \\
\text { Nüfus Miktarı }\end{array}$ & $\begin{array}{l}\text { Ekilebilir Arazi } \\
\text { intiyacı Olan } \\
\text { Nüfus Oranı (\%) }\end{array}$ \\
\hline 1 & Avustralya & 7.682 .300 & $6,0 \%$ & 1,90 & 459.898 & 24.190.907 & 46.461 & 413.437 & 215.265 .403 & $890 \%$ \\
\hline 2 & Kanada & 9.093 .510 & $4,8 \%$ & 1,21 & 437.660 & 36.109 .487 & 69.352 & 368.308 & 191.768 .047 & $531 \%$ \\
\hline 3 & Rusya Fed. & 16.376 .870 & $7,5 \%$ & 0,85 & 1.231 .218 & 144.342 .396 & 277.223 & 953.995 & 496.719 .086 & $344 \%$ \\
\hline 4 & ABD & 9.147 .420 & $16,6 \%$ & 0,47 & 1.522 .625 & 323.071 .342 & 620.489 & 902.136 & 469.717 .651 & $145 \%$ \\
\hline 7 & İspanya & 500.210 & $24,7 \%$ & 0,27 & 123.531 & 46.483 .569 & 89.276 & 34.255 & 17.835 .803 & $38 \%$ \\
\hline 8 & Türkiye & 769.630 & $26,5 \%$ & 0,26 & 203.810 & 79.821 .724 & 153.305 & 50.505 & 26.296 .542 & $33 \%$ \\
\hline 9 & Meksika & 1.943 .950 & $11,6 \%$ & 0,18 & 225.620 & 123.333 .376 & 236.873 & -11.253 & -5.859 .242 & $-5 \%$ \\
\hline 10 & Almanya & 348.880 & $33,7 \%$ & 0,14 & 117.468 & 82.348 .669 & 158.158 & -40.690 & -21.186 .110 & $-26 \%$ \\
\hline 11 & Hindistan & 2.973 .190 & $52,6 \%$ & 0,12 & 1.564 .630 & 1.324 .509 .589 & 2.543 .844 & -979.214 & -509.849 .747 & $-38 \%$ \\
\hline 12 & italya & 294.140 & $22,4 \%$ & 0,11 & 66.020 & 60.627 .498 & 116.441 & -50.421 & -26.252 .698 & $-43 \%$ \\
\hline 13 & Suudi Arabistan & 2.149 .690 & $1,6 \%$ & 0,11 & 34.770 & 32.442 .572 & 62.309 & -27.539 & -14.338 .789 & $-44 \%$ \\
\hline 14 & Birleşik Krallık & 241.930 & $24,9 \%$ & 0,09 & 60.260 & 65.595 .565 & 125.982 & -65.722 & -34.219 .788 & $-52 \%$ \\
\hline 20 & Kore Cumh. & 97.466 & $14,6 \%$ & 0,03 & 14.207 & 51.245 .707 & 98.422 & -84.215 & -43.848 .696 & $-86 \%$ \\
\hline & Dünya & 127.343 .220 & $11,1 \%$ & 0,19 & 14.083 .895 & 7.426.103.221 & 14.262 .522 & -178.627 & -93.006 .089 & \\
\hline
\end{tabular}

DKBDAM: Dünyada Kiși Bașına Düsen Ekilebilir Arazi Miktarı Ortalaması= 0,19 Hektar

Kaynak: Dünya Bankasının http://data.worldbank.org sitesinde yer alan nüfus, toplam arazi miktarı ve kişi başına düșen ekilebilir arazi miktarlarına ilişkin veriler kullanılarak tarafımızca hazırlanmıştır. 
Tablo 5'de yer alan 'Ekilebilir Arazi İhtiyacı Olan Nüfus Oranı' sütunundaki değerin negatif olduğu ülkeler, ekilebilir tarım arazisinin ülke nüfusunu beslemeye yetmediğini göstermektedir. Örneğin; Almanya'da kişi başına ekilebilir arazi miktarı dünya ortalamasının altında ve 0,14 hektar olarak gerçekleşmiştir. Almanya'nın mevcut nüfusunun ihtiyacını karşılayabilmesi için ilave $40.690 \mathrm{~km}^{2}$ ekilebilir tarım arazisine ihtiyacı bulunmaktadır. Bunun anlamı; Almanya yalnızca mevcut ekilebilir arazilerinde tarım ürünü üretirse nüfusunun yaklaşık 21 milyonluk kısmının ihtiyacını karşılayamamaktadır. Bu rakam mevcut nüfusun yüzde 26'sina denk gelmektedir.

Güney Kore'nin ekilebilir tarım arazisinin büyüklüğü, toplam nüfusunun yüzde 86'sının ihtiyacını karşılayamamaktadır. 16. sırada yer alan Çin'in ekilebilir arazisinin büyüklüğü, toplam nüfusunun yüzde 55'inin ihtiyacını karşılayamamaktadır. 8. sırada yer alan Türkiye'nin ekilebilir arazisinin büyüklüğü, toplam nüfusundan yüzde 33 daha fazla nüfusun ihtiyacını karşılayabilecek seviyededir. 4. sırada yer alan ABD'nin ekilebilir tarım arazisinin büyüklügü, toplam nüfusundan yüzde 145 daha fazla nüfusun ihtiyacını karş1layabilecek seviyededir. Yani ABD mevcut nüfusuna ilave olarak yaklaşık 470 milyon nüfusun tarım ürünleri ihtiyacını karşılayabilecek durumdadır. Tablodaki verilere göre ABD'nin ilave tarım arazisine ihtiyacı yoktur (Tablo 5).

Sınır ötesi tarım ihtiyacı olmadığı halde başta ABD olmak üzere birçok ülke sınır ötesi tarım yatırımı yapmaktadır. Tarım ürünlerinin yalnızca gıda amaçlı kullanılmayıp birçok endüstride girdi olarak kullanılıyor olmasının dışındaki en önemli neden; toprağın altından çıkarılmayıp üstünde yetiştirilen ve soft emtia olarak isimlendirilen kahve, kakao, şeker, misır, soya fasulyesi, buğday, pamuk gibi ürünlerin ticari değerinin çok yüksek olmasıdır (Tablo 5).

Sınır ötesi tarım yatırımı ticaretinin gelişmesiyle birlikte, katma değeri yüksek tarım ürünlerine olan talep de artmaktadır. Aynı zamanda, tarım piyasalarının yapısında da büyük değişim ve dönüşümler meydana gelmektedir. Biyoteknolojinin gelişimi, biyoyakıt üretimi, iklim değişikliğinin etkilerinin sinırlandırılması gibi hedefler sınır ötesi tarım yatırımı ticaretinin daha hızlı büyümesini ve gelişmesini sağlayacaktır (Byerlee vd., 2009: 3).

FAO ve OECD raporlarına göre; önümüzdeki 10 yıl içinde gıda fiyatlarında yüzde 40'a varan artışlar olacağı tahmin edilmektedir. Bu yüksek artışa bağlı olarak dünyada tekrar büyük bir gıda krizi ile karşılaşılması ihtimalinin uzak olmadığı uzmanlar tarafindan dile getirilmektedir. Özellikle tarım arazilerinin tarım dışı amaçlarla kullanılması ve gıda arzındaki sıkıntıların devam etmesi gibi sorunlar bu krizin derinleşmesine neden olacaktır (Dünya Bülteni, 2013), Tarım ürünlerine olan talebin son yıllarda hızla artması, ülkeleri sınır ötesi tarım yatırımı yapmaya mecbur hale getirmektedir. 
Sinır Ötesi Tarım Yatırımlarının Geleceği ve Ülkelerin Sinır Ötesi Tarım Yatırımı İhtiyacının Tespiti İçin Bir Yaklaşım

\section{Sonuç}

Tarımın geçmişi insanlık tarihi kadar eskilere dayanmaktadır. Tarım sektörü bireysel ihtiyacı karşılamak için üretim yapılan geçimlik tarımdan başlayarak birçok evrelerden geçerek günümüze kadar gelmiştir. Tarımın keşfi, insanoğlunu toprağa bağımlı hale getirmiştir. Tarım, sanayi devrimine kadar egemen sektör iken, 18. yüzyıldan itibaren ülkelerin ekonomik hayatlarında itici güç olmaktan çıkarak bir köprü vazifesi görmeye başlamıştır.

Ülkelerin sınır ötesi tarım yatırımı ihtiyacının ortaya çıkmasındaki önemli faktörlerden birisi de tarım arazilerinin yanlış kullanılmasıdır. Daha önce savaşlarla yeryüzünü şekillendiren insanoğlu sanayi devrimiyle fosil yakıtları ve demiri kullanarak yeni bir yaşam biçimi geliştirmiştir. Fabrikaların kurulması işçi ihtiyacını artırmış, bu çerçevede fabrikalar etrafinda yeni yaşam alanları oluşmaya başlamıştır. Bu gelişmelerin bir sonucu olarak yaşanan hızlı nüfus artışı doğal kaynaklar ve araziler üzerindeki baskıyı da artırmıştır. II. Dünya savaşı yıllarında sonra başlayan Yeşil Devrim ile tarımsal verimliliği artırmak için kullanılan tarım ilaçları ve gübreler ile bilinçsiz sulama yöntemlerinin yaygınlaşması tarım arazilerinin yanlış-bilinçsiz kullanımı hızlandırmıştır (Gülersoy, 2014: 123)

Bu sayılan faktörlerin dışında iklim değişikliği ve tarım alanlarının tarım dışı amaçlarla kullanılması gibi nedenlerle dünyadaki ekilebilir tarım arazileri her geçen gün azalmıştır. Buna karşın dünya nüfusu geçmiş yıllarda hiç olmadığı kadar hızlı bir şekilde artmıştır. Bundan 100 y1l önce dünya nüfusunun 100 milyon artması için 20 yıl gerekiyorken, yalnızca 2018 yılında dünya nüfusu 83,3 milyon artmıştır (World Bank, 2020). G1da güvenliğini tehdit eden bu nüfus artışı karşısında ülkeler çözüm arayışı içine girmişlerdir. Bugün itibariyle en pratik çözüm olarak sınır ötesi tarım yatırımı gündeme gelmiştir.

Sınır ötesi tarım yatırımının gerekliliği, tarım sektörünün yeniden şekillenmesini, tarım politikalarının revize edilmesini, tarımın ülkeler için ulusal güvenlik meselesi haline gelmesini ve tarım sektöründeki aktörlerin yeniden belirlenmesini zorunlu hale getirmiştir. 2018 ve 2019 yıllarında yaşanan ülkeler arasındaki ticaret savaşlarının en kritik gündem maddelerinden birisi tarım ürünleridir. Ülkeler ve küresel aktörler tarım ürünlerini artık bir silah gibi kullanmaya başlanmıştır. Özellikle 2020 yılının başından itibaren Çin'de ortaya çıktıktan sonra tüm kıtalara yayılan ve Dünya Sağlık Örgütü tarafından pandemik (dünya çağında salgına dönüşen) bir hastalık olarak ilan edilen Covid-19 (BBC Türkçe, 2020) gida ürünleri eksenli ticaret savaşlarını daha anlamlı hale getirmiştir.

Sınır ötesi tarım ticaretinin etkisiyle yüzyıllar boyunca küçük işletmeler veya devletler eliyle yürütülen tarım sektörü yavaş yavaş büyük şirketlerin kontrolüne geçmeye başlamıştır. Geleneksel tarım teknikleriyle dünyadaki gıda talebinin karşılanması artık imkansız hale gelmiştir. Modern ve akıllı tarım yöntemlerine olan ihtiyaç tarım sektöründeki mevcut aktörler olan küçük 
işletmeler ve devletlerin tasfiyesini hızlandırmıştır. Buna karşın sektörün ihtiyacı olan üretim süreçlerinin hızlı bir şekilde planlanması, koordinasyonu ve yönetilmesi görevini daha kolay ve pratik bir şekilde karşılama kabiliyeti olan küresel şirketler, sektörün yeni aktörleri haline gelmiştir. Sektörün geleceği, tohumdan ilaçlamaya, pazarlamadan ürün sevkiyatına kadar tüm süreçleri kontrol ve denetim altına alan az sayıdaki şirketin kontrolüne geçmiştir.

Yukarıdaki tespitler 1şığında; ülkelerin ekonomik gelişmişlik seviyesi ile gıda talebi arasında bir ilişki olduğu tespit edilmiştir. Sınır ötesi tarım yatırımı bu çerçevede ülkeler için bir çıkış yolu olarak görünmektedir. Sınır ötesi tarım yatırımlarının gıda talebini karşılama noktasında yeterli olabilmesi için bilgi teknolojileri, ar-ge ve endüstri 4.0 teknolojilerinin desteğiyle sürecin yönetilmesi kaçınılmaz hale gelmiştir.

\section{Kaynaklar}

Allafrica (2008), https://allafrica.com/stories/200804230844.html, (19.07.2018) Arbutina, Z., (2011) Yoksul ülkelerden "toprak araklaniyor", www.dw.com/tr/yoksul-ülkelerden-toprak-araklanıyor/a-15471740, (29.08.2017)

Artisien, P., (1985), Joint Ventures in Yugoslav Industry, Gower Publishing, England.

Aysu, A., (2015), Gida Krizi, 1.bs., İstanbul, Metis Yayınları.

Aysu, A., (2008), Küreselleşme ve Tarım Politikaları, 1.bs., İstanbul, Su Yayınları.

BBC Türkçe, (2020) 30 Mart 2020 tarihinde https://www.bbc.com/turkce/ haberler-dunya-51614548 adresinden alınd1.

Berstein, H., (2014), Tarımsal Değişimin Sinıfsal Dinamikleri, Çev. Oya Köymen, 2.bs., İstanbul, Yordam Kitap.

Byerlee, D., DE Janvry A., Sadoulet E., (2009), “Agriculture for Development: Toward a New Paradigm", Annual Review of Resource Economics, Vol. $1: 15$

Çakıc1 Sarpkaya, N., (2010), 9 Nisan 2018 tarihinde https:/www.xing.com/communities/posts/ zengin-uelkeler-fakirlerintarim-arazilerini-aliyor-1006983117 adresinden alınd.

Çaşkurlu, S., (2012) “Küresel Gıda Krizi: Üçüncü Gıda Rejimi, Küresel Sermaye Ve Gelişmekte Olan Ülkeler”, Ekonomik Yaklaşım, Cilt: 23 (Özel Sayı), ss.161-194.

Daniel, S., Mittal A., (2009) The Great Land Grab Rush for World's Farmland Threatens Food Security for The Poor, The Oakland Institute. Oakland, CA, USA.

Deininger, K., Byerlee D., (2011), Rising Global Interest in Farmland: Can it Yield Sustainable and Equitable Benefit? World Bank 
Sinır Ötesi Tarım Yatırımlarının Geleceği ve Ülkelerin Sinır Ötesi Tarım Yatırımı İhtiyacının Tespiti İçin Bir Yaklaşım

De Schutter, O., (2011) The Green Rush: The Global Race for Farmland and the Rights of Land Users, Volume 52, Number 2, Harvard International Law Journal, ss.504-556

Donat, İ., (2017), 11 Nisan 2018 tarihinde www.bloomberght.com/yorum /irfandonat/2034210-cinin-tarim-stratejisi, adresinden alındi.

Donat, İ., (2014), 27 Şubat 2019 tarihinde http://www.bloomberght.com/ analiz/haber/1551307-analiz-cin-ve-suudi-arabistan-tarim-arazilerinikapatiyor, adresinden alındi.

Dünya Bülteni (2013), 2 Temmuz 2019 tarihinde http://www.dunyabulteni.net/ haber/280614/afrikada-toprak-kiralama-yarisi adresinden alındı.

FAO (2012) World Agriculture Towards 2030/2050. The 2012 Revision

FAO (2013) World Food and Agriculture. Statistical Yearbook

Fortune Global (2015) http://beta.fortune.com/global500/, (20.07.2018)

Fortune Global (2017) https://fortune.com/global500/2017, (20.07.2018)

Grant, E., Das O., (2015) Land Grabbing, Sustainable Development and Human Rights. Transnational Environmental Law 4 (2). s.5.

Gülersoy, A. E., (2014) "Yanlış Arazi Kullanımı", Elektronik Sosyal Bilgiler Eğitimi Dergisi, Cilt:1, S:2

Gülersoy, A. E., Girgin, M. (2017) “Toprak Sömürüsünün Değişen Yüzü: Azgelişmiş ve Gelişmekte Olan Ülkelerde Arazi Kapatmaları (Arazi Satın Alımı / Kiralanmas1)", Doğu Coğrafya Dergisi: Ocak-2017, Yı1:22, say1:37, ss.147-158.

Kutluay, C., Turhan E., (2012) Dört Nala Krize: Arazi Kapatmalart Arttyor, Express 128, ss.34-35

Land Matrix (2016), International Land Deals for Agriculture.

Liu, P., (2014) Impacts of Foreign Agricultural Investment on Developing Countries FAO, Roma.

Messerli, P., Giger M., Dwyer M., B., Breu T., Eckert S., (2014), The Geography of Large-Scale Acquisitions: Analysing Socio-Ecological Patterns of Target Contexts in the Global South, Applied Geography, say1 53, ss.449459

Rey, B., (2010) "Addressing The Human Rights impact of Land Grabbing. European Union", Brussels.

Reyhan, H., (2014) "Ekolojik Emperyalizm Kuramına Giriş: Biyopolitik Bir Kavramsallaştırma”, Memleket Siyaset Yönetim, Cilt: 5, Sayı:14, ss.64103

Ricking, C., (2011), www.dw.com/tr/zenginlerin-gözü-yoksulun-toprağında/a14835335, (23.08.2017)

Rulli, M., Saviori C. A., D'Odorico Paolo. (2013) Global land and water grabbing, Department of Environmental Sciences, University of Virginia, Vol. 110, No.3

The World Factbook, (2018) https://www.cia.gov/library/publications/theworld-factbook/fields/2056.html (20.07.2018) 
Toprak Atlas1, (2015), Yayına Hazırlayan, Kristian Brakel, Heinrich Böll Stiftung Derneği Türkiye Temsilciliği, İstanbul.

Tutulmaz, O., (2012) Sürdürülebilir Kalkınma: Sürdürülebilirlik İçin Bir Çözüm Vizyonu Gaziantep Üniversitesi Sosyal Bilimler Dergisi, 2012, Volume 11, Issue 3, ss.601-626.

Türkeş, M., (2008) "Küresel iklim değişikliği nedir? Temel kavramlar, nedenleri, gözlenen ve öngörülen değişiklikler”, İklim Değişikliği ve Çevre, 1, ss.2637

Vox, (2014), 9 Haziran 2019 tarihinde https://www.vox.com/2014/11/20/ 7254883/farmland-trade-land-grab adresinden alınd1.

World Bank (2015), 29 Kasım 2017 tarihinde https://blogs.worldbank.org/ publicsphere/world-s-top-100-economies-31-countries-69-corporations adresinden alınd.

World Bank (2019), 20 Kasım 2019 tarihinde https://data.worldbank.org/ indicator/AG.LND.ARBL.ZS adresinden alındı.

World Bank (2020), 29 Mart 2020 tarihinde https://data.worldbank.org/ indicator/sp.pop.totl adresinden alınd. 